\title{
Selection of the Amino Acid and Saccharide That Increase the Tetracycline Susceptibility of Vibrio splendidus
}

\author{
Guohua Jiang ${ }^{1,2}$, Yanan $L^{1,2}$, Ya Li ${ }^{1,2}$, Weiwei Zhang ${ }^{1,2 *}$ and Chenghua $L^{1,2,3 *}$ \\ ${ }^{1}$ Collaborative Innovation Center for Zhejiang Marine High-efficiency and Healthy Aquaculture, Ningbo University, Ningbo, \\ China, ${ }^{2}$ State Key Laboratory for Quality and Safety of Agro-products, Ningbo University, Ningbo, China, ${ }^{3}$ Laboratory for \\ Marine Fisheries Science and Food Production Processes, Qingdao National Laboratory for Marine Science and Technology, \\ Qingdao, China
}

\section{OPEN ACCESS}

Edited by:

Lixing Huang,

Jimei University, China

Reviewed by:

Zhe Zhao,

Hohai University, China

Qingpi Yan,

Jimei University, China

*Correspondence:

Weiwei Zhang

zhangweiwei1@nbu.edu.cn

Chenghua $L i$

lichenghua@nbu.edu.cn

Specialty section:

This article was submitted to Veterinary Infectious Diseases,

a section of the journal

Frontiers in Veterinary Science

Received: 27 November 2021 Accepted: 17 December 2021 Published: 28 January 2022

Citation:

Jiang G, Li Y, Li Y, Zhang W and Li C (2022) Selection of the Amino Acid and Saccharide That Increase the Tetracycline Susceptibility of Vibrio splendidus. Front. Vet. Sci. 8:823332. doi: 10.3389/fvets.2021.823332
Bacterial persister cells are a subpopulation of isogenic bacteria with characteristics of reduced metabolic activity and multidrug antibiotic resistance. Our lab had previously proved that Vibrio splendidus could form persister cells both naturally and after stimulation. However, the conditions for the waking up of $V$. splendidus persister cells remain marginal. In this study, the carbon sources that could wake up V. splendidus persister cells were selected from 20 amino acids and eight saccharides. The result showed that L-glutamic acid, L-aspartic acid, L-arginine, L-phenylalanine, L-leucine, maltose, D-galactose, sorbitol, mannose, N-acetyl-D-glucosamine, D-glucose, and D-fructose could wake up the $V$. splendidus persister cells. The chemotaxis activity of both exponential cells and regrown persister cells on plate containing each of the selected carbon source are also high. The existence of the selected carbon source can affect the antibiotic susceptibility of $V$. splendidus. When L-glutamic acid, L-aspartic acid, L-phenylalanine, and D-glucose were separately added into the cultured $V$. splendidus simultaneously with tetracycline, $V$. splendidus could be completely eliminated, while the addition of L-alanine and D-galactose could not. Our study suggested that $V$. splendidus persister cells could revive in the presence of specific carbon sources, and the addition of these exogenous nutrients could increase the tetracycline susceptibility of $V$. splendidus.

Keywords: Vibrio splendidus, persister cells, carbon source, chemotaxis, antibiotic susceptibility

\section{INTRODUCTION}

Persister cells are a little potion of bacterial cells which are temporarily resistant to multidrug on account of a metabolic transient alteration (1). In the 1940s, it was found that some bacteria were not killed completely after treatment with antibiotics (2). In 1944, Bigger named these surviving subpopulation "persister cells" (3). Both groups determine that persister cells are dormant, and this conclusion has been corroborated from that time on $(4,5)$. Unlike resistant cells, the genes of the persister cells did not alter $(6,7)$, but they are a little potion of bacterial cells with a transient state of hypometabolic or dormancy that can help bacteria to survive the exterior stresses, such as antibiotic treatment and nutrient deficiency (8-11). Till now, this phenotype has been commonly found in Staphylococcus aureus, Pseudomonas aeruginosa, Escherichia coli, Vibrio splendidus and Archaea (12-14) during in vitro growth as well as infection in the host. 
Up to now, more and more studies have shown that persister cells play an important part in the resuscitation of infection diseases. Persister cells avoid antibiotic killing by reducing metabolism, and when the level of antibiotics in the external environment drops, the persister cells resume growing $(3,12$, $15,16)$. Therefore, the persister cells lead to low efficacy of antibiotic treatment and high occurance of repeated infection. Different kinds of persister cells use specific carbon sources to wake up. For example, the persister cells of $P$. aeruginosa resuscitated in the condition of L-proline (17), while the persister cells of E. coli revived in the presence of L-alanine (18). Furthermore, the carbon sources that wake up the persister cells affect the antibiotic susceptibility of persister cells. The changes in antibiotic susceptibility triggered by glucose are documented in E. coli, Vibrio cholerae, P. aeruginosa, and S. aureus (19-22). The antibiotic sensitivity of E. coli, S. aureus, Edwardsiella tarda, Edwardsiella piscicida, and $P$. aeruginosa are also affected by fructose, maltose, sucrose, leucine, glycine, and alanine (19-21, 23-25).

$V$. splendidus is a gram-negative bacterium that is ubiquitously presented in marine ecosystems (26), and it is a significant opportunistic bacterial pathogen which causes infection of marine shellfish and sea cucumber Apostichopus japonicus (2730). Our previous study showed that $V$. splendidus could form persister cells (14). To further know more about $V$. splendidus persister cells, the carbon sources that could wake up V. splendidus persister cells were selected in this study, and furthermore, a strategy for completely eliminating $V$. splendidus was proposed.

\section{MATERIALS}

\section{Bacterial Strains and Culture Conditions}

V. splendidus was cultured in $2216 \mathrm{E}$ medium at $28^{\circ} \mathrm{C}(1 \mathrm{~g}$ yeast extract; $5 \mathrm{~g}$ tryptone; and $0.01 \mathrm{~g} \mathrm{FePO}, 1 \mathrm{~L}$ seawater). M9 minimal medium was prepared as follows: $10 \mathrm{ml} 0.1 \mathrm{M} \mathrm{CaCl}_{2}$,

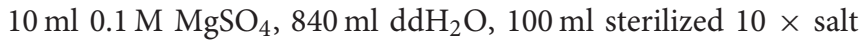
( $20 \mathrm{~g} \mathrm{NaCl}, 30 \mathrm{~g} \mathrm{KH}_{2} \mathrm{PO}_{4}, 70 \mathrm{~g} \mathrm{Na} \mathrm{HPO}_{4}, 10 \mathrm{~g} \mathrm{NH} 4 \mathrm{Cl}$ in $1 \mathrm{~L}$ $\mathrm{ddH}_{2} \mathrm{O}$ ). The concentration of each saccharide was $0.4 \%$, which was used to wake up $V$. splendidus persister cells. The amino acids and their corresponding levels used to wake up V. splendidus persister cells are listed in Table 1 (31). Tetracycline was dissolved in pure ethanol to make a stock solution of $10 \mathrm{mg} \cdot \mathrm{ml}^{-1}$.

\section{Selection of Persister Cells}

$V$. splendidus persister cells were prepared by lysing active cells with high concentration of tetracycline $400 \mu \mathrm{g} \cdot \mathrm{ml}^{-1}$, according to our previous study (14). Briefly, $10 \mathrm{ml}$ of overnight $V$. splendidus culture was mixed with $40 \mathrm{ml} 2216 \mathrm{E}$ containing 2,000 $\mu \mathrm{l}$ of tetracycline stock solution, and the culture was incubated $4 \mathrm{~h}$ in a shaker with a shaking speed of $150 \mathrm{rpm}$. The remaining bacteria were washed with $2 \% \mathrm{NaCl}$ three times. To verify whether these remaining cells were persister cells, we observed their status on agarose gel pads without any carbon sources as described by Kim et al. (32). In short, agarose was put into $44 \mathrm{ml}$ $\mathrm{ddH}_{2} \mathrm{O}$ at $1.5 \%$ and sterilized by autoclaving; then, $5 \mathrm{ml} 10 \times$ M9 salt solution, $0.5 \mathrm{ml} 0.01 \mathrm{M} \mathrm{CaCl}_{2}$, and $0.5 \mathrm{ml} 0.1 \mathrm{M} \mathrm{MgSO}_{4}$
TABLE 1 | Levels (5x concentration) of amino acids in M9 minimal medium.

\begin{tabular}{|c|c|c|c|}
\hline Amino acid & $\begin{array}{c}\text { Final } \\
\text { concentration } \\
(\mu \mathrm{g} / \mathrm{ml})\end{array}$ & Stock & $\begin{array}{l}\text { Amount } \\
\text { per liter }\end{array}$ \\
\hline L-alanine & 75 & $1 \%$ & $7.5 \mathrm{ml}$ \\
\hline L-arginine & 145 & $2 \%$ & $7.25 \mathrm{~m}$ \\
\hline L-asparagine & 75 & $1 \%$ & $7.5 \mathrm{ml}$ \\
\hline L-aspartic acid & 75 & $1 \%$ & $7.5 \mathrm{ml}$ \\
\hline L-cysteine & 50 & $2 \%$ & $2.5 \mathrm{ml}$ \\
\hline L-histidine & 42 & $2 \%$ & $2.1 \mathrm{ml}$ \\
\hline L-glutamic acid & 75 & $1 \%$ & $7.5 \mathrm{ml}$ \\
\hline L-glutamine & 75 & $1 \%$ & $7.5 \mathrm{ml}$ \\
\hline L-glycine & 110 & $2 \%$ & $5.5 \mathrm{ml}$ \\
\hline L-isoleucine & 42 & $1 \%$ & $4.2 \mathrm{ml}$ \\
\hline L-leucine & 41 & $1 \%$ & $4.1 \mathrm{ml}$ \\
\hline L-lysine & 75 & $1 \%$ & $7.5 \mathrm{ml}$ \\
\hline L-methionine & 25 & $2 \%$ & $1.25 \mathrm{~m}$ \\
\hline L-phenylalanine & 75 & $1 \%$ & $7.5 \mathrm{ml}$ \\
\hline L-proline & 164 & $4 \%$ & $4.1 \mathrm{ml}$ \\
\hline L-serine & 42 & $2 \%$ & $2.1 \mathrm{ml}$ \\
\hline L-threonine & 82 & $2 \%$ & $4.1 \mathrm{ml}$ \\
\hline L-tryptophan & 18 & $0.25 \%$ & $7.1 \mathrm{ml}$ \\
\hline L-tyrosine & 75 & $1 \%$ & $7.5 \mathrm{ml}$ \\
\hline L-valine & 42 & $1 \%$ & $4.2 \mathrm{ml}$ \\
\hline
\end{tabular}

solution were subsequently added before the gel was solidified. The cells were observed under the optical microscope (ZEISS) maintained at $28^{\circ} \mathrm{C}$.

\section{V. splendidus Persister Cells Revived on Amino Acids}

The selection of amino acid for the resuscitation of $V$. splendidus persister cells was determined as reported previously (17). Twenty amino acids were divided into four combinations, and five amino acids were in one group; \#1: Phe, Ala, Cys, Ser, and Arg, \#2: Tyr, Val, Gly, Thr, and His, \#3: Trp, Ile, Pro, Asn, and Lys, and \#4: Met, Leu, Gln, Glu, and Asp. To explore the recovery of persister cells on a single amino acid, we separately tested 15 amino acids in combination \#1, \#3, and \#4. V. splendidus persister cells were 10 -fold serially diluted, and $100 \mu \mathrm{l}$ of diluent were spread onto M9 minimal plates containing each kind of amino acid as carbon source, and the plates were incubated at $28^{\circ} \mathrm{C}$ for $96 \mathrm{~h}$.

\section{V. splendidus Persister Cells Revived on Saccharides}

Persister cells were also woken up by recognizing saccharides (18). To explore whether saccharides could be used as carbon source to resuscitate $V$. splendidus persister cells, eight saccharides, including maltose, D-glucose, D-ribose, mannose, D-galactose, sorbitol, $\mathrm{N}$-acetyl-D-glucosamine and D-fructose, were separately added into M9 minimal medium. These saccharides are chosen because they are usually good carbon 


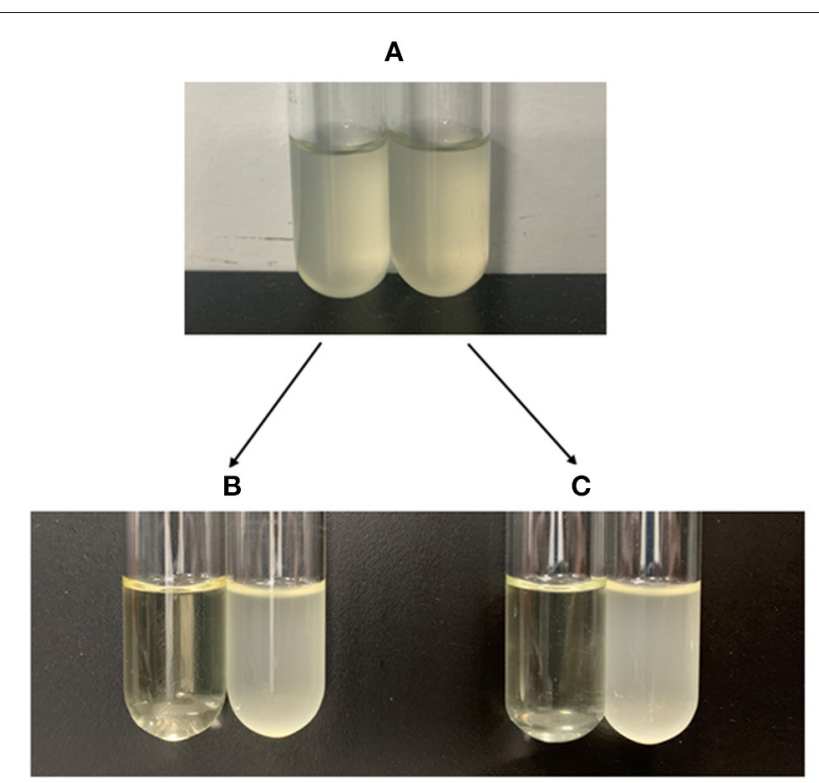

FIGURE 1 | The antibiotic susceptibility of the tetracycline-selected $V$. splendidus persister cells and $V$. splendidus cells. (A) The growth of $V$. splendidus exponential cells (left) and regrowth of $V$. splendidus persister cells (right); (B) the exponential cells of $V$. splendidus with (left) and without (right) 40 $\mu \mathrm{g} \cdot \mathrm{ml}^{-1}$ tetracycline treatment; $\mathbf{( C )}$ the regrown cells of $V$. splendidus persister cells with (left) and without (right) $40 \mu \mathrm{g} \cdot \mathrm{ml}^{-1}$ tetracycline treatment.

sources for bacteria, especially $N$-acetyl-D-glucosamine which is used as principal source of carbon and nitrogen by marine bacteria (33). V. splendidus persister cells were 10-fold serially diluted, and $100 \mu \mathrm{l}$ of diluent were spread onto M9 minimal plates containing each kind of saccharide as carbon source, and the plates were incubated at $28^{\circ} \mathrm{C}$ for $48 \mathrm{~h}$.

\section{Chemotaxis Assays}

The chemotaxis of both exponential cells and regrown persister cells were performed as reported previously by Weng et al. (34). Briefly, V. splendidus were cultured until an optical density at $600 \mathrm{~nm}\left(\mathrm{OD}_{600}\right)$ of 1.0 and washed twice with M9 minimal medium. V. splendidus persister cells were obtained as previously described, and the persister cells were put into $1 \mathrm{ml} \mathrm{M9} \mathrm{minimal}$ medium. Amino acid or saccharide solutions were separately added onto M9 minimal plates containing 0.2\% (w/v) agar. Ten microliter of bacterial suspensions were dropped on the M9 minimal plates containing each kind of individual carbon source, respectively, and the plates were incubated at $28^{\circ} \mathrm{C}$ for $96 \mathrm{~h}$.

\section{Antibiotic Susceptibility}

The overnight grown stationary phase culture was supplemented with each exogenous carbon source at levels of $0,1,5,10,15$, 20,30 , and $40 \mathrm{mM}$, respectively, and tetracycline stock solution was added into the medium at a concentration of $400 \mu \mathrm{g} \cdot \mathrm{ml}^{-1}$ immediately. The culture without addition of any exogenous carbon sources was used as a control. All the cultures were incubated at $28^{\circ} \mathrm{C}$ for $6 \mathrm{~h}$ with shaking at $150 \mathrm{rpm}$. After treatment, the cells were collected by centrifugation, diluted in

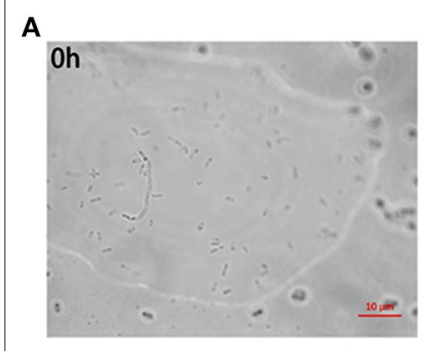

B
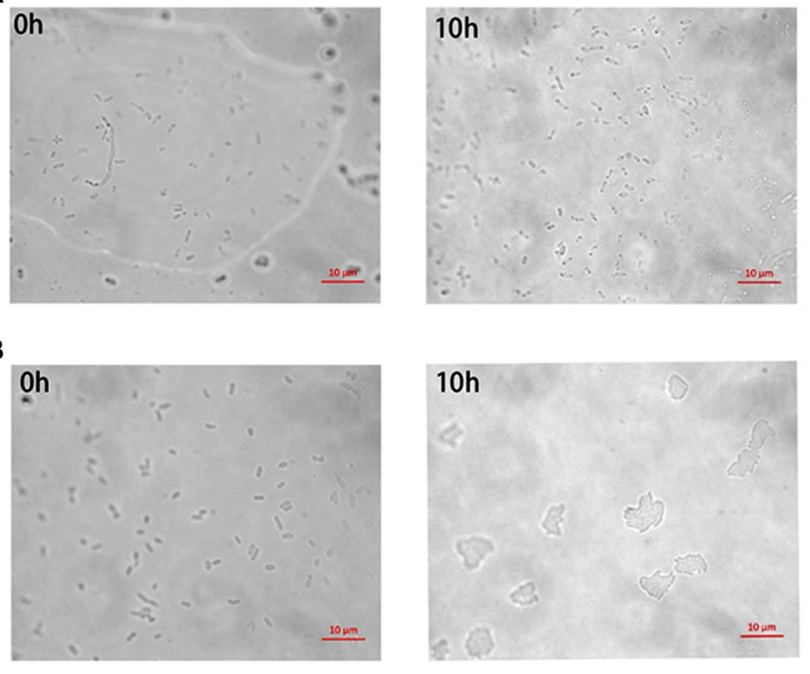

FIGURE 2 | The division of $V$. splendidus persister cells and $V$. splendidus exponential cells in the lack of nutrition. (A) Division of $V$. splendidus persister cells on M9 minimal gel pads that without nutrition at the time points of $\mathrm{O}$ h and $10 \mathrm{~h}$, respectively. (B) Division of $V$. splendidus exponential cells at time points of $\mathrm{Oh}$ and $10 \mathrm{~h}$ in the lack of nutrition. Scale bar indicates $10 \mu \mathrm{m}$.

10 -fold serially, and $10 \mu \mathrm{l}$ of each diluent was dropped on $2216 \mathrm{E}$ plates. After incubation at $28^{\circ} \mathrm{C}$ for $24 \mathrm{~h}$, the colonies that emerged on the plates were counted. The relative percent of survival was determined as follows: the cell number after tetracycline plus exogenous carbon source challenge/the cell number after tetracycline solo challenge.

\section{Strain Number and Statistical Analysis}

The isolates of $V$. splendidus were deposited into the China General Microbiological Culture Collection (CGMCC, Beijing, China) with strain No. 7.242. Statistical analyses were performed by using the two tailed $t$-test. Statistical significance was determined by one-way ANOVA. In all cases, the significance level was defined as ${ }^{*} p<0.05$ and ${ }^{* *} p<0.01$.

\section{RESULTS}

\section{Tetracycline-Selected $V$. splendidus Persister Cells}

A portion of antibiotic-resistant $V$. splendidus cells emerged after $400 \mu \mathrm{g} \cdot \mathrm{ml}^{-1}$ tetracycline was treated for $4 \mathrm{~h}$ at $28^{\circ} \mathrm{C}$. These cells were confirmed as persister cells by measuring their antibiotic sensitivity and cell division. The result showed that the regrown cells from persister cells had equal susceptibility to the tetracycline, and $40 \mu \mathrm{g} \cdot \mathrm{ml}^{-1}$ tetracycline could completely lyse both the regrown cells from persister cells and the exponential cells (Figure 1). The division of cells in the absence of nutrients was observed under microscope. It showed that the persister cells did not resuscitate within $10 \mathrm{~h}$ on agarose gel pads without nutrients (Figure 2A), while exponential cells of $V$. splendidus showed several divisions on agarose gel pads (Figure 2B). All 


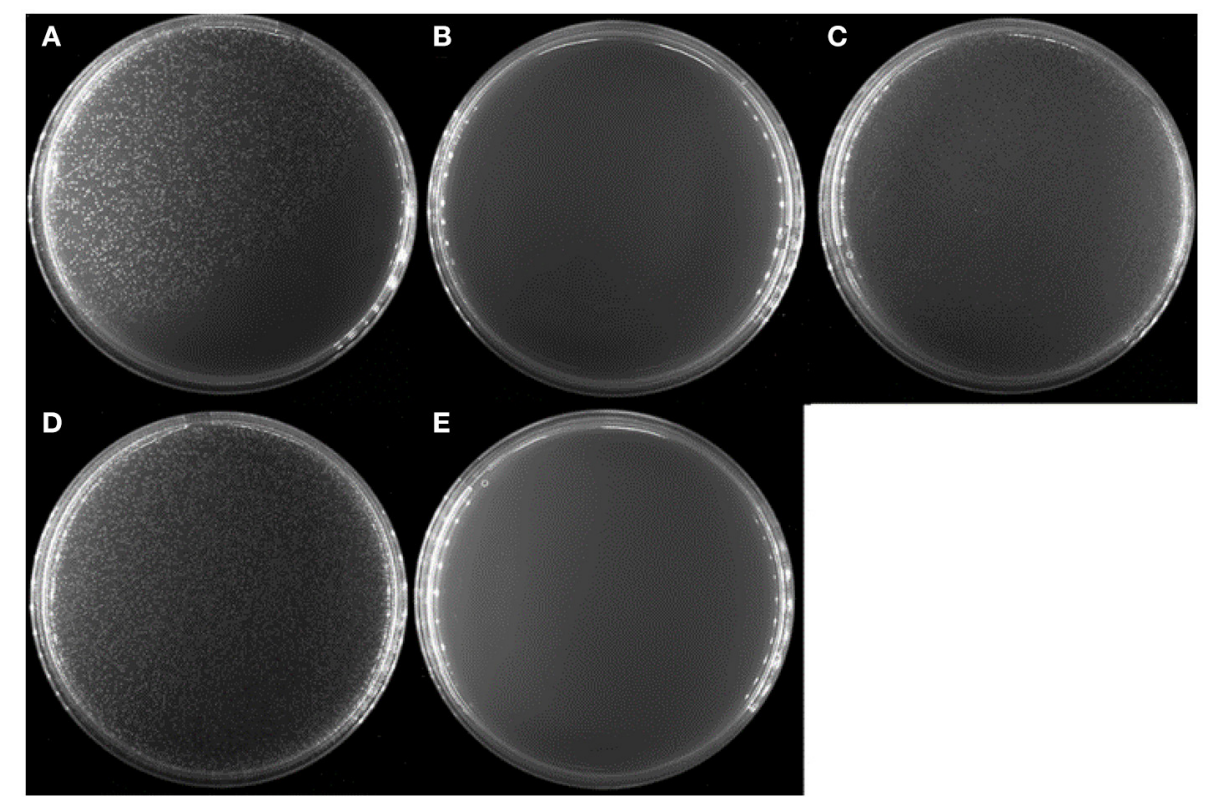

FIGURE 3 | Persister cells wake up on amino acids combination plate agar. $\mathrm{V}$. splendidus persister cells were incubated at $28^{\circ} \mathrm{C}$ for $96 \mathrm{~h}$ on $\mathrm{M} 9 \mathrm{minimal}$ plate agar with four different amino acid combinations, respectively: (A) \#1: Phe, Ala, Cys, Ser, and Arg; (B) \#2: Tyr, Val, Gly, Thr, and His; (C) \#3: Trp, lle, Pro, Asn, and Lys; (D) \#4: Met, Leu, Gln, Glu, and Asp; (E) without amino acid. All amino acids in the experiment were $5 \times$ concentration as listed in Table 1.

these results showed that the cells obtained after treatment with high concentration of tetracycline were persister cells. In addition, the persister cells in the stationary culture of $V$. splendidus were determined to be at a potion of approximately $0.1 \%-1 \%$ determined by the colony that emerged on the plates.

\section{V. splendidus Persister Cells Resuscitated on Specific Amino Acid}

To see whether $V$. splendidus persister cells could resuscitate on specific carbon source like the spores of Bacillus subtilis, a total of 20 amino acids were separately used as carbon source to wake up $V$. splendidus persister cells. For the first assay, we divided 20 amino acids into four groups as four kinds of carbon sources. The result showed that $V$. splendidus persister cells did not resuscitate on combination \#2, but they could resuscitate on combinations \#1, \#3, and \#4 (Figure 3). The 15 amino acids in combinations \#1, \#3, and \#4 were further chosen to detect the single amino acid to wake up V. splendidus persister cells. Result showed that $V$. splendidus persister cells woke up at $17 \mathrm{~h}$ when L-glutamic acid was used as the only carbon source, which was the fastest among all the 20 amino acids (Figure 4). V. splendidus persister cells revived on M9 minimal plate with L-aspartic acid at $24 \mathrm{~h}$, and they revived on M9 minimal plates with solo Lleucine, L-phenylalanine, and L-arginine when the resuscitation time increased to $40 \mathrm{~h}$ (Figure 4).

\section{V. splendidus Persister Cells Resuscitated on Specific Saccharide}

To see whether $V$. splendidus persister cells could resuscitate on saccharides, eight different kinds of saccharides were separately used as carbon source for $V$. splendidus persister cells to revive. Our result showed that $V$. splendidus persister cells revived on M9 minimal plate supplemented with D-galactose and maltose at $24 \mathrm{~h}$ and they revived on mannose and sorbitol at $36 \mathrm{~h}$, but $V$. splendidus persister cells slowly revived on M9 agar plate with separate $\mathrm{D}$-fructose, $\mathrm{N}$-acetyl-D-glucosamine, and D-glucose when the resuscitation time increased to $48 \mathrm{~h}$. Less colony numbers were obtained when the persister cells were revived on $\mathrm{D}$-fructose and $\mathrm{D}$-glucose, but larger colonies were obtained when they were revived on $\mathrm{D}$-fructose and D-glucose compared with $\mathrm{N}$-acetyl-D-glucosamine. However, V. splendidus persister cells did not revive with $\mathrm{D}$-ribose at all within $48 \mathrm{~h}$ (Figure 5).

\section{V. splendidus Showed Chemotaxis in Different Carbon Sources}

In the experiment to assess the chemotaxis ability of exponential cells and regrown cells of $V$. splendidus persister cells in the context of various carbon sources, three amino acids of Lglutamic acid, L-aspartic acid, and L-phenylalanine and two saccharides of D-galactose and D-glucose were chosen. L-alaine that could not revive the persister cells was selected to be used as a control. Ten microliters of each kind of cells was dropped on $0.2 \%$ M9 minimal plate containing each carbon source. We found that both exponential cells and regrown persister cells of $V$. splendidus showed obvious chemotaxis to $400 \mathrm{mg} \cdot \mathrm{l}^{-1} \mathrm{~L}$ glutamic acid, L-aspartic acid, L-phenylalanine, D-galactose, and D-glucose. After $96 \mathrm{~h}$ of treatment, the diameters of the $V$. splendidus on the plates containing L-alanine, L-aspartic acid, Lglutamic acid, L-phenylalanine, D-galactose, and D-glucose were, 


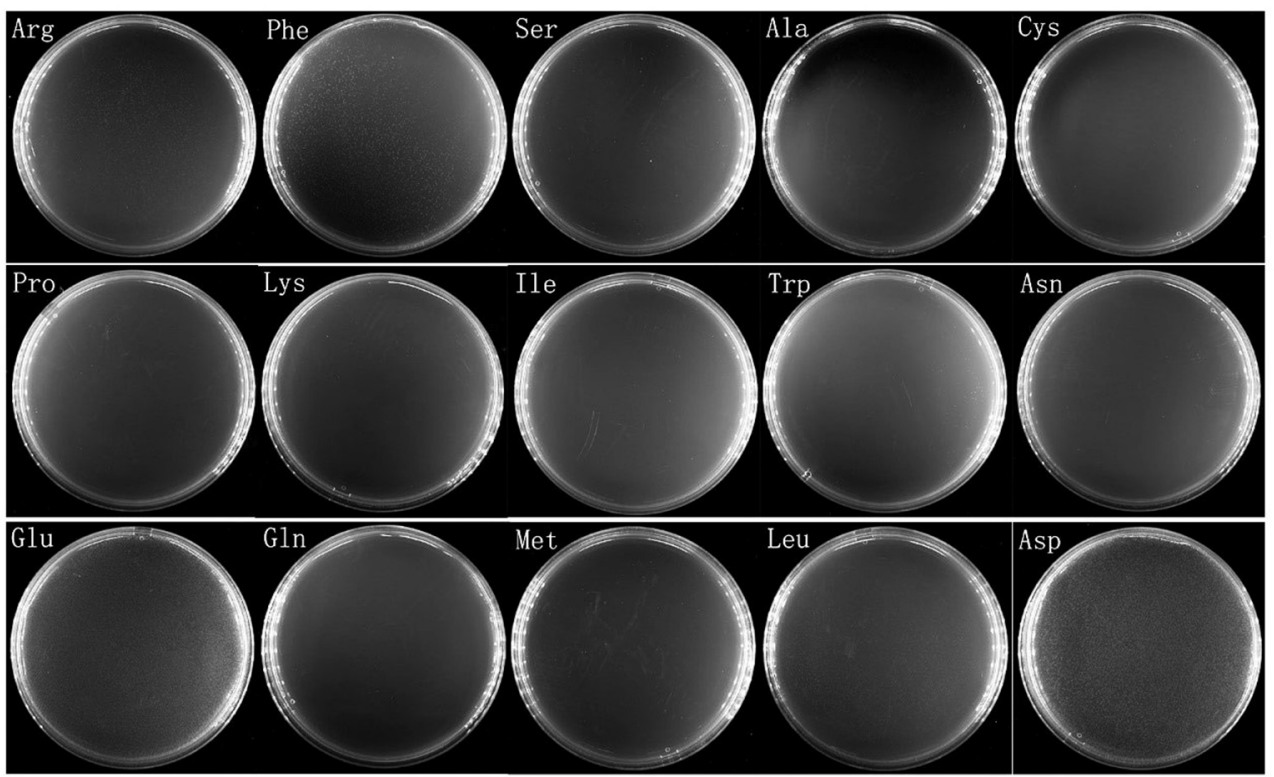

FIGURE 4 | Persister cells wake up on plate containing single amino acid. V. splendidus persister cells were incubated at $28^{\circ} \mathrm{C}$ for $96 \mathrm{~h}$ on M9 minimal plate with 15 individual amino acids (L-alanine, L-serine, L-cystine, L-arginine, L-lysine, L-phenylalanine, L-asparagine, L-proline, L-isoleucine, L-tryptophan, L-glutamine, L-leucine, $L$-aspartic acid, L-methionine, and L-glutamic acid). The concentrations of the amino acids in the experiment were $5 \times$ concentration as listed in Table $\mathbf{1 .}$

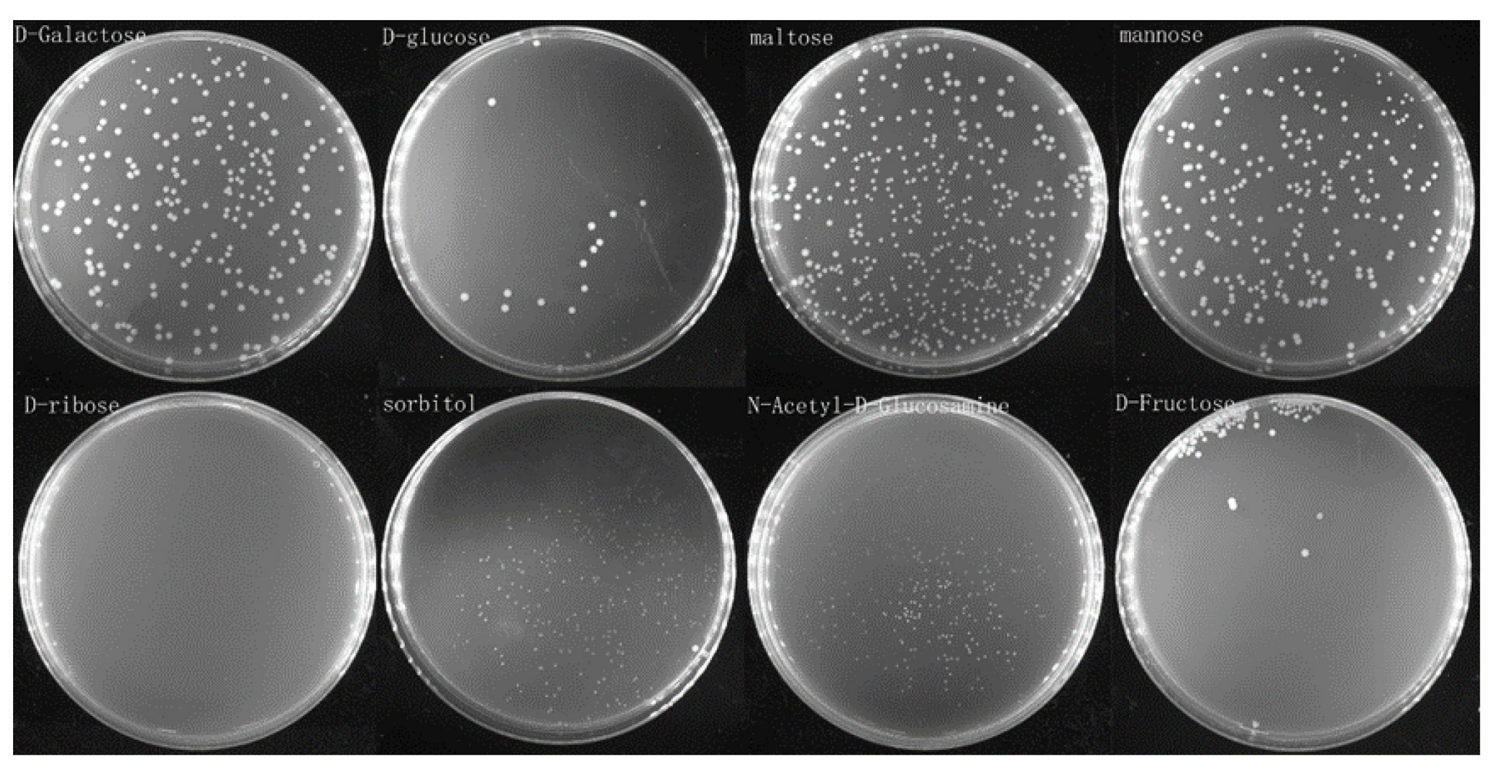

FIGURE 5 | Persister cells wake up on plate containing single saccharide. Persister cells were spread on M9 minimal plates with D-glucose, D-fructose, D-ribose, $\mathrm{N}$-acetyl-D-glucosamine, D-galactose, mannose, maltose, and sorbitol, respectively. The concentration of each saccharide on the plate was $0.4 \%$, and the plates were incubated at $28^{\circ} \mathrm{C}$ for $48 \mathrm{~h}$.

respectively, $3.13,8.67,8.65,4.06,9.93$, and $8.74 \mathrm{~cm}$, respectively (Figure 6), and the diameters of the regrown $V$. splendidus persister cells on the L-alanine, L-aspartic acid, L-glutamic acid, L-phenylalanine, D-galactose, and D-glucose plates were 1.93, $6.69,8.15,3.17,8.57$, and $5.48 \mathrm{~cm}$, respectively (Figure 7). The chemotaxis of both exponential cells and regrown persister cells of $V$. splendidus showed the highest chemotaxis ability toward D-galactose and L-glutamic acid. On the contrary, the regrown cells of $V$. splendidus persister cells were not attracted by Lalanine within the $72 \mathrm{~h}$. 


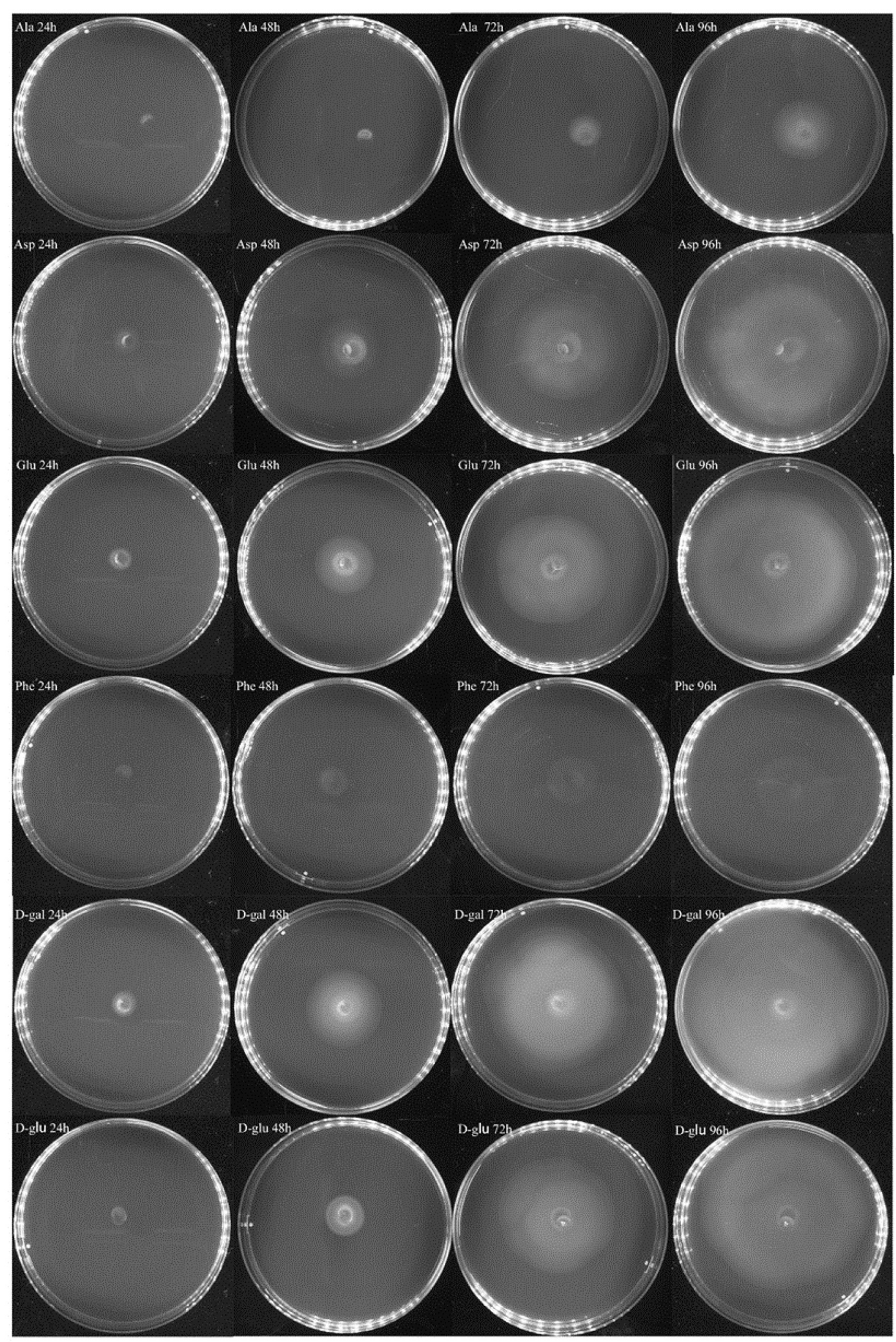

FIGURE 6 | Chemotaxis of $V$. splendidus exponential cells. Each exogenous carbon source at a concentration of $400 \mathrm{mg} \cdot \mathrm{L}^{-1}$ was separately added into M9 minimal plates containing $0.20 \%(\mathrm{w} / \mathrm{v})$ agar; $1 \mathrm{ml} \mathrm{M9}$ minimal medium was used to resuspend persister cells, and $10 \mu \mathrm{l}$ cell suspensions was dropped on the M9 minimal plate containing each carbon source, and the plates were incubated at $28^{\circ} \mathrm{C}$ for $96 \mathrm{~h}$. 


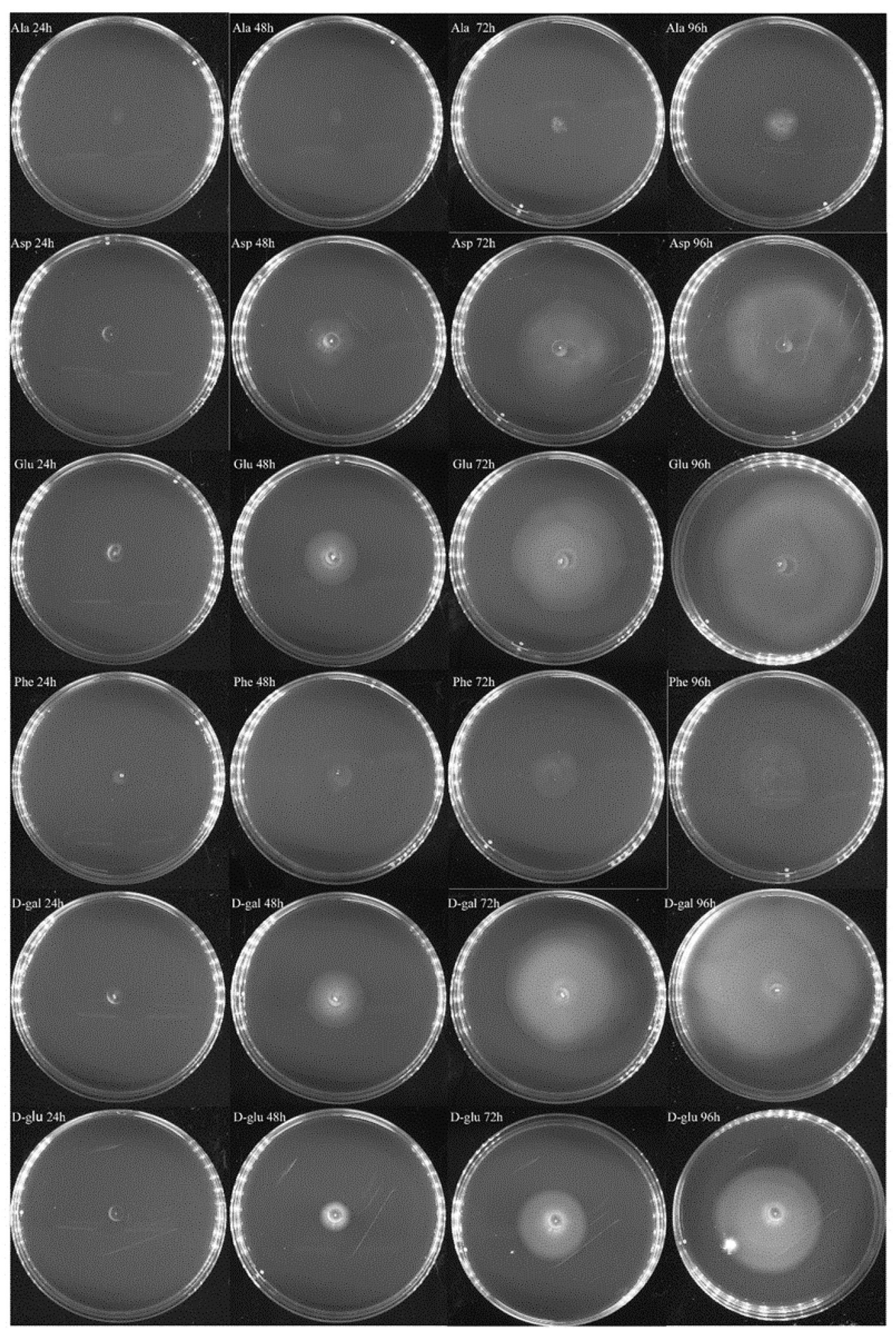

FIGURE 7 | Chemotaxis of the regrown cells of $V$. splendidus persister cells. Each exogenous carbon source at a concentration of $400 \mathrm{mg} \cdot \mathrm{L}^{-1}$ was separately added into M9 minimal plates containing $0.20 \%$ (w/V) agar; $1 \mathrm{ml}$ M9 minimal medium was used to resuspend persister cells, and $10 \mu \mathrm{l}$ bacterial suspension was dropped on M9 plate containing each carbon source, and the plates were incubated at $28^{\circ} \mathrm{C}$ for $96 \mathrm{~h}$. 


\section{A}

A-1

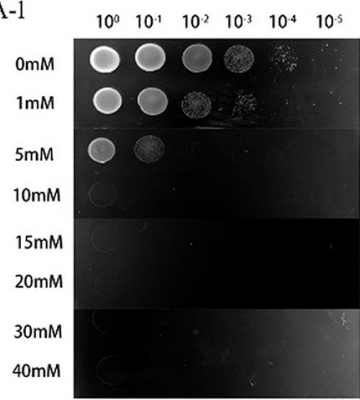

A-2

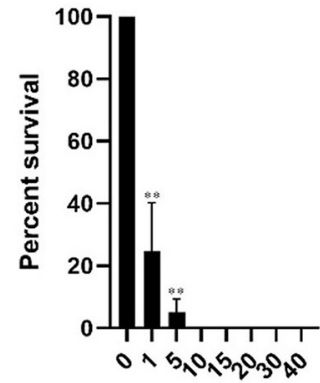

L-glutamic acid(mM)

D

D-1

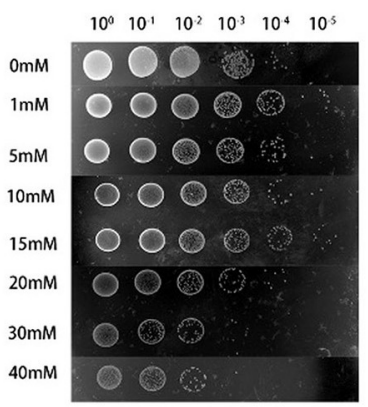

D-2

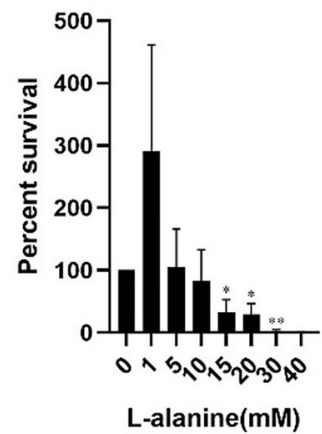

\section{B}

B-1

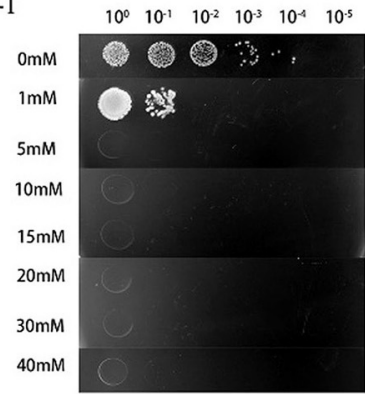

B-2

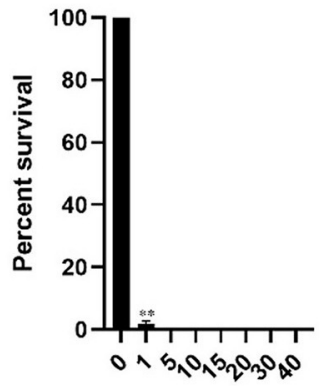

L-aspartic acid(mM)

E

E-1

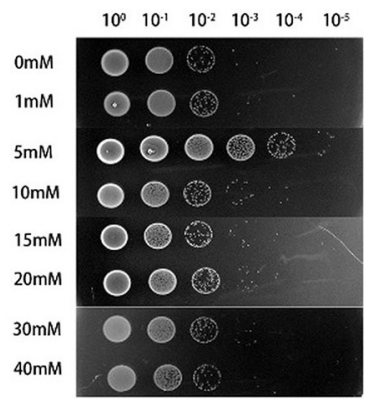

E-2

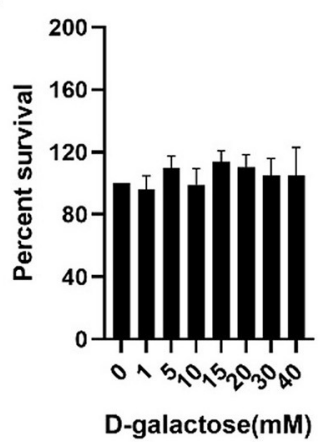

C

C-1

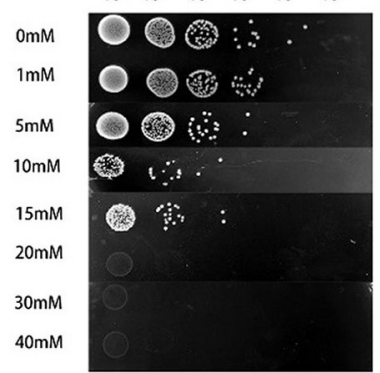

C-2

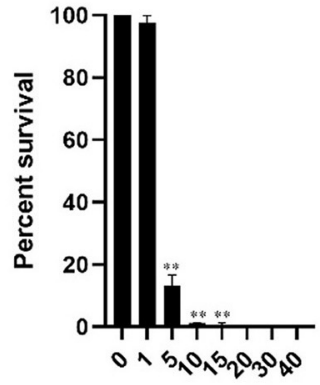

L-phenylalanine(mM)

F

F-1

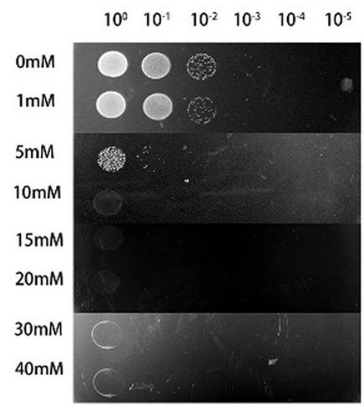

F-2

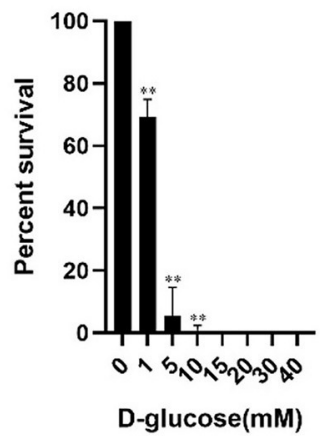

FIGURE 8 | Effects of exogenous carbon sources on antibiotic susceptibility of $V$. splendidus. The overnight grown stationary phase culture was supplemented with the following concentrations of exogenous metabolites: (A) L-glutamic acid, (B) L-aspartic acid, (C) L-phenylalanine, (D) L-alanine, (E) D-galactose, and (F) D-glucose. The cultures without addition of any exogenous carbon sources were used as a control. The antibiotics and exogenous carbon sources were simultaneously added to the culture and incubated for $6 \mathrm{~h}$, and the survived cells in different dilutions was represented by the colony formed on the plates $\left(10^{0}, 10^{-1}\right.$, $10^{-2}, 10^{-3}, 10^{-4}$, and $10^{-5}$ meant no dilution, 10-, 100-, 1,000-, 10,000- and 100,000- dilutions). The relative percent of survival was calculated as follows: the cell number after tetracycline plus exogenous carbon source challenge/the cell number after tetracycline challenge alone. ${ }^{*} p<0.05$ and ${ }^{* *} p<0.01$. 


\section{Exogenous Carbon Source Increased Tetracycline Susceptibility of $\boldsymbol{V}$. splendidus}

Studies have proved that the sensitivity of $E$. coli persister cells to aminoglycoside antibiotics is affected by exogenous glucose (23). In our present study, we tested whether the selected six metabolites, L-glutamic acid, L-aspartic acid, Lphenylalanine, L-alanine, D-galactose, and D-glucose could be used to increase the tetracycline susceptibility of $V$. splendidus. The results showed that the percentage of survived cells decreased with increased dose of L-glutamic acid, L-aspartic acid, Lphenylalanine, L-alanine, and D-glucose, with simultaneous addition of tetracycline (Figure 8). $V$. splendidus cells that were incubated with $400 \mu \mathrm{g} \cdot \mathrm{ml}^{-1}$ tetracycline alone for $6 \mathrm{~h}$ were used as a control sample, and approximately $0.1 \%-1 \%$ cells survived after tetracycline treatment. Compared to $V$. splendidus grown in $400 \mu \mathrm{g} \cdot \mathrm{ml}^{-1}$ tetracycline alone, the potion of the survived cells with the addition of carbon sources decreased significantly. The effect of exogenous carbon sources on the antibiotic sensitivity of $V$. splendidus was determined to be dose-dependent. The antibiotic sensitivity of $V$. splendidus also enhances when the concentrations rose from 0 to $40 \mathrm{mM}$. When the concentrations of L-aspartic acid, L-glutamic acid, D-glucose, and L-phenylalanine were $5,10,15$, and $20 \mathrm{mM}, V$. splendidus cells were completely killed by $400 \mu \mathrm{g} \cdot \mathrm{ml}^{-1}$ tetracycline; however, compared to $V$. splendidus in the control sample, the percentage of cell survival in the sample supplemented with $40 \mathrm{mM}$ D-galactose showed no obvious change. These results suggested that the antibiotic susceptibility could be increased by addition of exogenous carbon sources.

\section{DISCUSSION}

Persister cells refer to a state of reduced metabolic activity that endows a subpopulation of isogenic bacteria with temporary multi-drug resistance, and they are able to revive the growth after the external stress is relieved. The development of persister cells can affect antibiotic efficacy, leading to incomplete treatment and repeated infections (35). Different kinds of bacterial persister cells have their preferred carbon source to wake up. The persister cells of $P$. aeruginosa revived in L-proline (17), while the persister cells of $E$. coli recovered in the presence of Lalanine (18). This study is the first attempt to explore the carbon sources that could wake up $V$. splendidus persister cells. $V$. splendidus persister cells can revive in the context of the amino acids including L-glutamic acid, L-aspartic acid, L-phenylalanine, L-leucine and L-arginine, and saccharides including D-galactose, maltose, mannose, sorbitol, D-fructose, $\mathrm{N}$-acetyl-D-glucosamine, and D-glucose. For amino acids, Lglutamic acid revived $V$. splendidus persister cells used for the shortest time, and for saccharides, D-galactose, maltose, mannose, and sorbitol woke up $V$. splendidus persister cells better than $\mathrm{D}$-fructose, $\mathrm{N}$-acetyl-D-glucosamine, and D-glucose. The different numbers of colonies emerged on the specific carbon source probably attributed to the high heterogeneity of $V$. splendidus persister cells in dormancy (14), which resulted in their heterogeneous waking up on different carbon sources, probably due to different metabolism of various carbon sources in V. splendidus. Consequently, the results of this study indicated that (1) V. splendidus persister cells woke up responding to nutrient incentives similar to P. aeruginosa and E. coli $(17,18,36)$ (2) L-glutamic acid is the best amino acid to revive $V$. splendidus persister cells, which is specific to this bacterial species; this further strengthened the concept that different bacterial persister cells preferred to use different carbon sources to wake up (17, 18).

Chemotaxis is the response to the stimulation of chemical substances in the external environment (37). Bacteria receive signals from external stimuli through chemoreceptors and process them through signal transduction systems to make corresponding movements (38). Chemotaxis plays an important role in the recovery of $E$. coli persister cells. Once persister cells resuscitated, the cells use chemotaxis to gain nutrients (18). In this study, we found that both exponential cells and persister cells of $V$. splendidus showed obvious chemotaxis to L-glutamic acid, L-aspartic acid, L-phenylalanine, D-galactose, and D-glucose; but relative to L-glutamic acid, L-aspartic acid, D-galactose, and $\mathrm{D}$-glucose $V$. splendidus showed lower chemotaxis to $\mathrm{L}$ phenylalanine, and L-alaine. The carbon sources that persister cells showed stronger chemotaxis were consist with the carbon sources that were suitable for the revival of persister cells, which suggested that the chemotaxis system may also play important roles in recognizing nutritional signals and resuscitation in $V$. splendidus persister cells, similarly to that in E. coli persister cells (18).

Further, we tested the effect of these exogenous carbon sources on the antibiotic susceptibility of $V$. splendidus. The addition of exogenous nutrients increases the antibiotic susceptibility of bacteria and has been reported in various pathogens. For example, glucose can alter cell metabolism, which leads to increased sensitivity to kanamycin and ciprofloxacin $(22,24)$ and aminoglycosides $(21,23)$, and this phenomenon is also found in $V$. parahaemolyticus, K. peneumoniae, S. aureus, and $P$. aeruginosa (39-44). In the present study, we found that addition of exogenous carbon sources, L-glutamic acid, L-aspartic acid, Lphenylalanine, and D-glucose could also increase the tetracycline susceptibility of $V$. splendidus persister cells and this led us to speculate that these exogenous additions might trigger the little potion of persister cells at stationary phase to secede the persister state and enter into an active metabolic state. Compared with other methods to eliminate persister cells, such as development of new drugs, this method shows more effectiveness in combating antibiotic-resistant bacteria (24). Thus, we can surely believe that adding of the selected exogenous carbon sources combined with proper antibiotics will be a useful strategy to completely eliminate V. splendidus.

\section{DATA AVAILABILITY STATEMENT}

The original contributions presented in the study are included in the article/supplementary material, further inquiries can be directed to the corresponding authors. 


\section{AUTHOR CONTRIBUTIONS}

GJ conducted the experiments, analyzed the data, and wrote the original manuscript. YanL conducted parts of the experiments and analyzed the data. YaL conducted parts of the experiments. $\mathrm{WZ}$ conceived and planned the research, supervised the research, revised the manuscript, and acquired funding. CL supervised the research and acquired funding. All authors reviewed the manuscript.

\section{REFERENCES}

1. Helaine S, Kugelberg E. Bacterial persisters: formation, eradication, and experimental systems. Trends Microbiol. (2014) 22:41724. doi: 10.1016/j.tim.2014.03.008

2. Hobby GL, Meyer K, Chaffee E. Observations on the mechanism of action of penicillin. Exp Biol Med. (1942) 50:281-5. doi: 10.3181/00379727-50-13773

3. Bigger JW. Treatment of staphylococcal infections with penicillin-by intermittent sterilisation. Lancet. (1944) 2:497500. doi: 10.1016/S0140-6736(00)74210-3

4. Shah D, Zhang ZG, Khodursky A, Kaldalu N, Kurg K, Lewis K. Persisters: a distinct physiological state of E. coli BMC Microbiol. (2006) 6:53. doi: 10.1186/1471-2180-6-53

5. Kwan BW, Valenta JA, Benedik MJ, Wood TK. Arrested protein synthesis increases persister-like cell formation. Antimicrob Agents Ch. (2013) 57:146873. doi: 10.1128/AAC.02135-12

6. Kwan BW, Chowdhury N, Wood TK. Combatting bacterial infections by killing persister cells with mitomycin C. Environ Microbiol. (2015) 17:440614. doi: 10.1111/1462-2920.12873

7. Chowdhury N, Wood TL, Martinez-Vazquez M, Garcia-Contreras R, Wood TK. DNA-crosslinker cisplatin eradicates bacterial persister cells. Biotechnol Bioeng. (2016) 113:1984-92. doi: 10.1002/bit.25963

8. Bernier SP, Létoffé S, Delepierre M, Ghigo JM. Biogenic ammonia modifies antibiotic resistance at a distance in physically separated bacteria. Mol Microbiol. (2011) 81:705-16. doi: 10.1111/j.1365-2958.2011. 07724.x

9. Maisonneuve E, Gerdes K. Molecular mechanisms underlying bacterial persisters. Cell. (2014) 157:539-48. doi: 10.1016/j.cell.2014. 02.050

10. Martins PMM, Merfa MV, Takita MA, De Souza AA. Persistence in phytopathogenic bacteria: do we know enough? Front Microbiol. (2018) 9:1099. doi: 10.3389/fmicb.2018.01099

11. Song S, Wood TK. Post-segregational killing and phage inhibition are not mediated by cell death through toxin/antitoxin systems. Front Microbiol. (2018) 9:814. doi: 10.3389/fmicb.2018. 00814

12. Fisher RA, Gollan B, Helaine S. Persistent bacterial infections and persister cells. Nat Rev Microbiol. (2017) 15:453-64. doi: 10.1038/nrmicro.2017.42

13. Megaw J, Gilmore BF. Archaeal persisters: persister cell formation as a stress response in Haloferax volcanii. Front Microbiol. (2017) 8:1589. doi: 10.3389/fmicb.2017.01589

14. Li YN, Wood TK, Zhang WW, Li CH. Vibrio splendidus persister cells induced by host coelomic fluids show a similar phenotype to antibiotic-induced counterparts. Environ Microbiol. (2021) 23:5605-20. doi: $10.1111 / 1462-2920.15717$

15. Lewis K. Persister cells. Annu Rev Microbiol. (2010) 64:35772. doi: 10.1146/annurev.micro.112408.134306

16. Van den Bergh B, Fauvart M, Michiels J. Formation, physiology, ecology, evolution and clinical importance of bacterial persisters. FEMS Microbiol Rev. (2017) 41:219-51. doi: 10.1093/femsre/ fux001

17. Zhang WW, Yamasaki R, Song S, Wood TK. Interkingdom signal indole inhibits Pseudomonas aeruginosa persister cell waking. J App Microbiol. (2019) 127:1768-72. doi: 10.1111/jam.14434

\section{FUNDING}

This study was funded by the Zhejiang Provincial Natural Science Foundation for Distinguished Young Scholar (LR20C190001), the National Natural Science Foundation of China (31972833), the Zhejiang Provincial Natural Science Foundation (LZ19C190001), the Fundamental Research Funds for the Provincial Universities of Zhejiang (SJLZ2020001), and the K.C. Wong Magna Fund at Ningbo University.

18. Yamasaki R, Song S, Benedik MJ, Wood TK. Persister cells resuscitate using membrane sensors that activate chemotaxis, lower cAMP levels, and revive ribosomes. iScience. (2019) 23:100792. doi: 10.1016/j.isci.2019.100792

19. Thorsing M, Bentin T, Givskov M, Tolker-Nielsen T, Goltermann L. The bactericidal activity of $\beta$-lactam antibiotics is increased by metabolizable sugar species. Microbiology. (2015) 161:1999-2007. 2 doi: 10.1099/mic.0.000152

20. Prax M, Mechler L, Weidenmaier C, Bertram R. Glucose augments killing efficiency of daptomycin challenged Staphylococcus aureus persisters. PLoS ONE. (2016) 11:e0150907. doi: 10.1371/journal.pone.0150907

21. Meylan S, Porter CBM, Yang JH, Belenky P, Gutierrez A, Lobritz MA. Carbon sources tune antibiotic susceptibility in Pseudomonas aeruginosa via tricarboxylic acid cycle control. Cell Chem Biol. (2017) 24:195206. doi: 10.1016/j.chembiol.2016.12.015

22. Paranjape SS, Shashidhar R. Glucose sensitizes the stationary and persistent population of Vibrio cholerae to ciprofloxacin. Arch Microbiol. (2020) 202:343-9. doi: 10.1007/s00203-019-01751-8

23. Allison KR, Brynildsen MP, Collins JJ. Metabolite-enabled eradication of bacterial persisters by aminoglycosides. Nature. (2011) 473:216-20. doi: 10.1038/nature10069

24. Peng B, Su Y, Li H, Han Y, Guo C, Tian Y, et al. Exogenous alanine and/or glucose plus kanamycin kills antibiotic-resistant bacteria. Cell Metab. (2015) 21:249-62. doi: 10.1016/j.cmet.2015.01.008

25. Ye J, Lin X, Cheng Z, Su Y, Li W, Ali F, et al. Identification and efficacy of glycine, serine and threonine metabolism in potentiating kanamycinmediated killing of Edwardsiella piscicida. J Proteomics. (2018) 183:3444. doi: 10.1016/j.jprot.2018.05.006

26. Macián MC, Garay E, González-Candelas F, Pujalte MJ, Aznar R. Ribotyping of Vibrio populations associated with cultured oysters (Ostrea edulis). Syst Appl Microbiol. (2020) 23:409-17.-2020(00)800727 doi: 10.1016/S0723-2020(00)80072-7

27. Beaz-Hidalgo R, Balboa S, Romalde JL, Figueras MJ. Diversity and pathogenecity of Vibrio species in cultured bivalve molluscs. Environ Microbiol Rep. (2010) 2:34-43. doi: 10.1111/j.1758-2229.2010.00135.x

28. Lemire A, Goudenège D, Versigny $\mathrm{T}$, Petton $\mathrm{B}$, Calteau $\mathrm{A}$, Labreuche $\mathrm{Y}$, et al. Populations, not clones, are the unit of vibrio pathogenesis in naturally infected oysters. ISME J. (2015) 9:1523-31. doi: 10.1038/ismej.20 14.233

29. Travers MA, Miller BK, Roque A, Friedman CS. Bacterial diseases in marine bivalves. J Invertebr Pathol. (2015) 131:11-31. doi: 10.1016/j.jip.2015.07.010

30. Zhang WW, Li CH. Virulence mechanisms of vibrios belonging to the Splendidus clade as aquaculture pathogens, from case studies and genome data. Rev Aquacult. (2021) 13:2004-026. doi: 10.1111/raq.12555

31. Rodriguez R, Tait RC. Recombinant DNA Techniques: An Introduction. Menlo Park, CA: Benjamin Cummings Publishing Company. (1983)

32. Kim JS, Chowdhury N, Yamasaki R, Wood TK. Viable but non-culturable and persistence describe the same bacterial stress state. Environ Microbiol. (2018) 20:2038-48. doi: 10.1111/1462-2920.14075

33. Keyhani NO, Roseman S. Physiological aspects of chitin catabolism in marine bacteria. Biochim Biophys Acta. (1999) 1473:10822. doi: 10.1016/S0304-4165(99)00172-5

34. Weng Y, Jiang JD, Deng HH, Lan H, Li SP. Effect of mutation of chemotaxis signal transduction gene cheA in Pseudomonas putida DLL-1 on its chemotaxis and methyl parathion biodegradation. Wei Sheng Wu Xue Bao. (2007) 47:471-6. 
35. Lewis K. Platforms for antibiotic discovery. Nat Rev Drug Discov. (2013) 12:371-87. doi: 10.1038/nrd3975

36. Kim JS, Yamasaki R, Song S, Zhang W, Wood TK. Single cell observations show persister cells wake based on ribosome content. Environ Microbiol. (2018) 20:2085-98. doi: 10.1111/1462-2920. 14093

37. Karmakar R. State of the art of bacterial chemotaxis. J Basic Microbiol. (2021) 61:366-79. doi: 10.1002/jobm.202000661

38. Porter SL, Wadhams GH, Armitage JP. Signal processing in complex chemotaxis pathways. Nat Rev Microbiol. (2011) 9:153-65. doi: 10.1038/nrmicro2505

39. Gusarov I, Shatalin K, Starodubtseva M, Nudler E. Endogenous nitric oxide protects bacteria against a wide spectrum of antibiotics. Science. (2009) 325:1380-4. doi: 10.1126/science.1175439

40. Lee HH, Molla MN, Cantor CR, Collins JJ. Bacterial charity work leads to population-wide resistance. Nature. (2010) 467:825. doi: 10.1038/nature09354

41. Barbieri E, Falzano L, Fiorentini C, Pianetti A, Baffone W, Fabbri A, et al. Occurrence, diversity, and pathogenicity of halophilic Vibrio spp. and NonO1 Vibrio cholerae from estuarine waters along the Italian Adriatic coast. App Environ Microbiol. (1999) 65:2748-53. doi: 10.1128/AEM.65.6.2748-27 53.1999

42. Shatalin K, Shatalina E, Mironov A, Nudler E. $\mathrm{H}_{2} \mathrm{~S}$ : a universal defense against antibiotics in bacteria. Science. (2011) 334:98690. doi: 10.1126/science. 1209855
43. Vega NM, Allison KR, Khalil AS, Collins JJ. Signalingmediated bacterial persister formation. Nat Chem Biol. (2012) 8:431-3. doi: 10.1038/nchembio.915

44. Vega NM, Allison KR, Samuels AN, Klempner MS, Collins JJ. Salmonella typhimurium intercepts Escherichia coli signaling to enhance antibiotic tolerance. PNAS USA. (2013) 110:14420-5. doi: 10.1073/pnas.1308085110

Conflict of Interest: The authors declare that the research was conducted in the absence of any commercial or financial relationships that could be construed as a potential conflict of interest.

Publisher's Note: All claims expressed in this article are solely those of the authors and do not necessarily represent those of their affiliated organizations, or those of the publisher, the editors and the reviewers. Any product that may be evaluated in this article, or claim that may be made by its manufacturer, is not guaranteed or endorsed by the publisher.

Copyright (c) 2022 Jiang, Li, Li, Zhang and Li. This is an open-access article distributed under the terms of the Creative Commons Attribution License (CC BY). The use, distribution or reproduction in other forums is permitted, provided the original author(s) and the copyright owner(s) are credited and that the original publication in this journal is cited, in accordance with accepted academic practice. No use, distribution or reproduction is permitted which does not comply with these terms. 